\title{
PENGEMBANGAN BAHAN AJAR TEMATIK BERBASIS SCIENTIFIC UNTUK SISWA KELAS IV SD TEMA TEMPAT TINGGALKU SUB TEMA KEUNIKAN DAERAH TEMPAT TINGGALKU
}

\author{
Nyai Cintang \\ Universitas Sultan Agung, Semarang, Indonesia \\ Email: nyaicintang@gmail.com
}

\begin{abstract}
ABSTRAK
Abstract Factual conditions require the development of teaching materials in thematic learning using a scientific approach to improve the available teaching materials. This study aims to: 1) examine the factual conditions for the use of teaching materials in thematic learning in the 2013 curriculum; 2) knowing the development of scientific based thematic teaching materials for fourth grade elementary students; 3) knowing expert judgment on the feasibility of scientific-based thematic teaching materials for fourth grade elementary students; 4) knowing the effect of the use of scientifically based thematic teaching materials on the learning achievement of fourth grade elementary school students; 5) knowing the teacher's assessment of learning using thematically based thematic teaching materials for grade IV elementary school students; 6) knowing the response of students to learning using thematically based thematic teaching materials for fourth grade elementary school students. This study uses Development Research with qualitative and quantitative research designs. The development process uses the 4-D model of Thiagarajan, Semel and Semel which has been modified to be the stage of defining, designing, and developing. Teaching materials that have been validated by experts get the category of "very valid and without revision" from expert responses and teacher evaluations with agreed criteria, student responses to the use of teaching materials in learning get very good responses from students. The results of the trials using the experimental design The Before And After Design show that there is an effect of the use of scientifically based thematic teaching materials on the learning achievement of PPKn; 2) there is the influence of the use of scientifically based thematic teaching materials on social studies learning achievements; 3) there is the influence of the use of scientifically based thematic teaching materials on the learning achievement of science. Scientific based thematic teaching materials for Grade IV Primary School students can be used in learning.
\end{abstract}

Keywords : Teaching Material, Thematic, Scientific, and 4-D development model.

Abstrak. Kondisi faktual membutuhkan adanya pengembangan bahan ajar pada pembelajaran tematik menggunakan pendekatan saintifik untuk menyempurnakan produk bahan ajar yang telah tersedia. Penelitian ini menggunakan Penelitian Pengembangan dengan desain penelitian kualitatif dan kuantitatif yang bertunjuan untuk : 1) mengkaji kondisi faktual pemanfaatan bahan ajar pada pembelajaran tematik di kurikulum 2013; 2) mengetahui pengembangan bahan ajar tematik berbasis saintifik untuk siswa SD kelas IV; 3) mengetahui penilaian pakar terhadap kelayakan bahan ajar tematik berbasis saintifik untuk siswa SD kelas IV; 4) mengetahui pengaruh pemanfaatan bahan ajar tematik berbasis saintifik terhadap prestasi belajar siswa SD kelas IV; 5) mengetahui penilaian guru terhadap pembelajaran menggunakan bahan ajar tematik berbasis saintifik untuk siswa SD kelas IV; 6) mengetahui respon siswa terhadap pembelajaran menggunakan bahan ajar tematik berbasis 
saintifik untuk siswa SD kelas IV. Proses pengembangan menggunakan model 4-D Thiagarajan, Semel and Semel yang telah dimodifikasi menjadi tahap pendefinisian, perancangan, dan pengembangan. Bahan ajar yang telah divalidasi oleh pakar mendapatkan kategori "sangat valid dan tanpa revisi" dari respon pakar dan penilaian guru dengan kriteria setuju, respon siswa terhadap pemanfaatan bahan ajar dalam pembelajaran memperoleh respon sangat baik dari siswa. Hasil uji coba menggunakan desain eksperimen The Before And After Design menunjukkan terdapat pengaruh pemanfaatan bahan ajar tematik berbasis saintifik terhadap prestasi belajar PPKn; 2) terdapat pengaruh pemanfaatan bahan ajar tematik berbasis saintifik terhadap prestasi belajar IPS; 3) terdapat pengaruh pemanfaatan bahan ajar tematik berbasis saintifik terhadap pretasi belajar IPA. Bahan ajar tematik berbasis saintifik untuk siswa Sekolah Dasar kelas IV dapat digunakan dalam pembelajaran.

Kata kunci : Bahan Ajar, Tematik, Saintifik, dan model pengembangan 4-D.

\section{PENDAHULUAN}

Kurikulum 2013 menuntut adanya daya kreativitas guru dalam pelaksanaannya. Standar kompetensi lulusan yang tertuang pada kurikulum 2013 menuntut siswa untuk memiliki kemampuan faktual dan konseptual melalui pembelajaran tematik berbasis saintifik. Perangkat penunjang pembelajaran tematik pada kurikulum 2013 yang telah disediakan pemerintah ternyata masih memerlukan pengembangan agar landasan awal perubahan kurikulum dapat tercapai sesuai target. Kedudukan buku guru sebagai panduan bagi guru dalam membuat sekenario pembelajaran ternyata belum maksimal. Materi yang terdapat pada buku guru dan buku siswa adalah materi berskala nasional artinya tidak terdapat penyajian materi berskala lokal, sedangkan menurut Jean Piaget tahap berpikir siswa sekolah dasar masih pada tahap operasional kongkret, sehingga siswa memerlukan pembelajaran yang nyata, kontekstual dan pembelajaran yang ada di sekitar siswa agar siswa dapat membangun pengetahuannya sesuai dengan teori konstruktivisme. Oleh karena itu, perlu dikembangkan materi berskala lokal untuk memfasilitasi siswa sesuai dengan tahap berpikirnya.

Beberapa guru masih mengalami kesulitan dalam melaksanakan pembelajaran tematik yakni dalam mengalihkan antara muatan pelajaran satu ke muatan pelajaran yang lainnya agar hakikat pembelajaran tematik tidak pudar. Nuansa pembelajaran tematik selaras dengan tahap perkembangan siswa sekolah dasar yang kongkret, holistik dan integratif. Berdasarkan analisis PISA (2011) menyatakan bahwa tingkat pemahaman, pendalaman dan penguasaan materi siswa di Indonesia masih sangat rendah. Proses pembelajaran yang selama ini dilakukan belum mampu menggali kemampuan siswa untuk memberikan alasan dengan informasi yang lengkap, mengelola informasi, membuat generalisasi, dan menyajikan data. Hal tersebut dapat diwujudkan dengan menerapkan pendekatan saintifik dengan langkah-langkah ilmiah yaitu mengamati, menanya, mengumpulkan informasi, mengolah informasi, dan mengkomunikasikan. Langkah-langkah ilmiah mampu mengembangkan kemampuan siswa dalam menalar, berpikir logis, kritis dan analitis. Hasil penelitian Permata (2014) bahwa "pendekatan saintifik dapat meningkatkan kemampuan berpikir kritis".

Kedudukan bahan ajar sangat penting dalam kegiatan pembelajaran. Bahan ajar merupakan sumber belajar yang disusun secara sistematis untuk menunjang pelaksanaan proses belajar mengajar secara maksimal. Oleh karena itu guru perlu mengembangkan bahan ajar yang dapat menunjang pembelajaran tematik sekaligus dapat memfasilitasi siswa dengan materi 
berskala lokal sesuai dengan lingkungan yang ada di sekitar siswa.

Rumusan masalah dari penelitian ini yaitu : 1) bagaimana kondisi faktual pemanfaatan bahan ajar pada pembelajaran tematik di kurikulum 2013; 2) bagaimana pengembangan bahan ajar tematik berbasis saintifik untuk siswa SD kelas IV; 3) bagaimana penilaian pakar terhadap kelayakan bahan ajar tematik berbasis saintifik untuk siswa SD kelas IV?; 4) Apakah pengaruh pemanfaatan bahan ajar tematik berbasis saintifik terhadap prestasi belajar siswa SD kelas IV; 5) bagaimana penilaian guru terhadap pembelajaran menggunakan bahan ajar tematik berbasis saintifik untuk siswa SD kelas IV; 6) bagaimana respon siswa terhadap pembelajaran menggunakan bahan ajar tematik berbasis saintifik untuk siswa SD kelas IV.

Tujuan dari penelitian ini yaitu : 1) mengkaji kondisi faktual pemanfaatan bahan ajar pada pembelajaran tematik di kurikulum 2013; 2) mengetahui pengembangan bahan ajar tematik berbasis saintifik untuk siswa SD kelas IV; 3) mengetahui penilaian pakar terhadap kelayakan bahan ajar tematik berbasis saintifik untuk siswa SD kelas IV; 4) mengetahui pengaruh pemanfaatan bahan ajar tematik berbasis saintifik terhadap prestasi belajar siswa SD kelas IV; 5) mengetahui penilaian guru terhadap pembelajaran menggunakan bahan ajar tematik berbasis saintifik untuk siswa SD kelas IV; 6) mengetahui respon siswa terhadap pembelajaran menggunakan bahan ajar tematik berbasis saintifik untuk siswa SD kelas IV.

Daryanto dan Dwicahyono (2014: 171) "bahan ajar adalah segala bentuk bahan yang digunakan untuk membantu guru dalam melaksanakan kegiatan belajar mengajar di kelas". Prastowo (2013: 279) "bahan ajar tematik adalah bahan ajar yang mengandung karakteristik pembelajaran tematik, sehingga mampu mengoptimalkan pelaksanaan pembelajaran tematik".
Kementrian Pendidikan dan Kebudayaan BPSDMP dan KPMP (2013) "pembelajaran tematik terpadu dilaksanakan dengan menggunakan prinsip pembelajaran terpadu. Pembelajaran terpadu menggunakan tema sebagai pemersatu kegiatan pembelajaran yang memadukan beberapa mata pelajaran sekaligus dalam satu kali tatap muka, untuk memberikan pengalaman yang bermakna bagi peserta didik". Prastowo (2013: 313) "bahan ajar tematik harus memunculkan berbagai karakteristik dasar pembelajaran tematik yaitu 1) menstimulasi siswa agar aktif; 2) menciptakan suasana pembelajaran yang menyenangkan (joyful learning); 3) menyuguhkan pengetahuan yang holistik (tematik); dan 4) memberikan pengalaman langsung (direct experiences).“

BPSDMP dan KPMP (2013) "proses pembelajaran dapat dipadankan dengan suatu proses ilmiah. Pendekatan ilmiah yang dimaksud merupakan pendekatan scientific dalam pembelajaran yang meliputi mengamati, menanya, menalar, mencoba, membentuk jejaring untuk semua mata pelajaran". Abdullah (2014: 53) menyatakan "tahapan aktivitas belajar yang dilakukan dengan pembelajaran saintifik tidak harus dilakukan melalui prosedur yang kaku, namun dapat disesuaikan dengan pengetahuan yang hendak dipelajari”.

\section{METODE PENELITIAN}

Penelitian ini menggunakan desain penelitian kualitatif dan kuantitatif dengan metode penelitian dan pengembangan. Strategi yang diguanakan adalah eksploratoris sekuensial. Penelitian diawali dengan pengumpulan dan analisis data kualitatif yang selanjutnya dijadikan landasan pengembangan menggunakan tahap 4-D (Define, Design, Develop, Desseminate) yang dikemukkakan oleh Thiagarajan, Semmel and Semmel. Penelitian ini dibatasi hanya sampai tahap develop. Uji coba sekala terbatas dilakukan untuk mengetahui respon dan pengaruh penggunaan bahan ajar dalam kegiatan 
pembelajaran. Desain eksperimen yang digunakan adalah The Before and After Design dengan menggunakan uji t sampel berpasangan. Teknik yang digunakan dalam pengumpulan data adalah tes dan nontes. Teknik tes berupa pretes dan postes sedangnkan teknik nontes yaitu menggunakan instrumen validasi pakar/ahli, instrumen penilaian guru, dan angket respon siswa untuk mengetahui respon dari produk yang telah dihasilkan.

\section{HASIL DAN PEMBAHASAN}

Kondisi faktual menunjukkan bahwa perlu perlu dikembangkan bahan ajar tematik berbasis saintifik pada pembelajaran tematik di kurikulum 2013. Hasil kanjian kondisi faktual yang diperoleh dari hasil wawancara meliputi: 1) guru masih kesulitan dalam melaksanakan pembelajaran tematik, yakni dalam menghubungkan antar muatan pelajaran satu ke muatan pelajaran lain agar hakikat pembelajaran tematik tidak pudar; 2) kurangnya kedalaman materi pada buku guru dan buku peserta didik sehingga guru harus mencari materi tambahan untuk memaksimalkan pembelajaran; 3) materi yang terdapat pada buku guru dan buku peserta didik masih merupakan materi berskala nasional, sementara itu menurut Jean Piaget tahap berpikir peserta didik sekolah dasar berada pada tahap operasional kongkret dimana peserta didik memerlukan pembelajaran yang nyata, kontekstual dan sesuai dengan apa yang terdapat di sekitar peserta didik.

Hasil kajian kondisi faktual yang diperoleh dari analisis buku guru dan buku siswameliputi : 1) terdapat kesalahan konsep materi, yakni terdapat kesalahan pemberian informasi terhadap gambar; 2) kegiatan saintifik tidak difasilitasi secara maksimal. Kesimpulannya, bahan ajar yang telah disediakan belum mampu memfasilitasi peserta didik dalam melakukan pembelajaran di kurikulum 2013, yakni menggunakan pendekatan saintifik.

Kegiatan saintifik dilakukan dengan langkah-langkah ilmiah yaitu mengamati, menanya, menalar, mengumpulkan informasi, dan mengkomunikasikan. Kurikulum 2013 mengunakan kegiatan saintifik karena sesuai dengan prosedur ilmiah sehingga, peserta didik lebih mudah untuk memahami suatu konsep. Kegiatan saintifik dimulai dengan pengamatan, sehingga objek pengamatan harus jelas dan memfasilitasi peserta didik dalam menemukan suatu konsep. Kenyataannya objek pengamatan yang terdapat pada buku peserta didik belum sesuai dengan konsep yang harus ditemukan; 3) tuntutan kurikulum tidak diimbangi dengan perangkat pembelajaran yang baik. Setiap akhir pembelajaran, pada buku siswa terdapat penugasan berupa kegiatan kerjasama dengan orang tua namun tidak dijelaskan langkah-langkah yang dapat dilakukan peserta didik untuk menyelesaikan tugas tersebut. Fungsi penugasan tersebut agar peserta didik lebih mendalami konsep materi pembelajaran.

Deskripsi pengembangan bahan ajar tematik berbasis saintifik menggunakan model 4-D sebagai berikut :1) pendefinisian (Define), menetapkan dan mendefinisikan syarat-syarat penyusunan dan batasan materi yang akan dikembangkan pada bahan ajar tematik berbasis saintifik melalui langkah-langkah analisis awal-akhir, analisis siswa, analisis konsep, analisis tugas, analisis dan perumusan tujuan pembelajaran; 2) perancangan (Design) menghasilkan bahan ajar tematik meliputi muatan pelajaran PPKn, IPS dan IPA berbasis pendekatan saintifik yaitu mengamati objek, menanya, mengumpulkan informasi, mengolah informasi yang terdiri dari kegiatan menalar, mengasosiasi, dan menemukan hubungan antar konsep serta mengkomunikasikan baik secara lisan maupun tulisan. Hasil pada tahap perancangan (design) ini disebut draft I; 3) pengembangan (Develop) menghasilkan draft final bahan ajar tematik berbasis saintifik yang baik dan telah dilakukan validasi oleh pakar. Kegiatan pada tahap pengembangan adalah validasi ahli dan uji coba sekala terbatas. Sebelum dilakukan 
uji coba pada subjek yang telah ditentukan. Bahan ajar yang telah dibuat terlebih dahulu dilakukan validasi oleh pakar/ahli untuk menyempurnakan produk yang telah dibuat sehingga layak untuk digunakan. Validasi dilakukan sebanyak dua kali. Validasi pertama menghasilkan nilai ratarata total sebesar 3,7 dengan kesimpulan layak digunakan dengan revisi. Setelah dilakukan revisi, kemudian dilakukan validasi kedua yang menghasilkan nilai rata-rata total sebesar 4,9 dengan kesimpulan layak digunakan tanpa revisi. Validasi dilakukan dengan oleh dua pakar yang meliputi : 1) pakar pembelajaran tematik; 2) pakar struktur bahan ajar dan bahasa. Hasil validasi sebagai berikut :
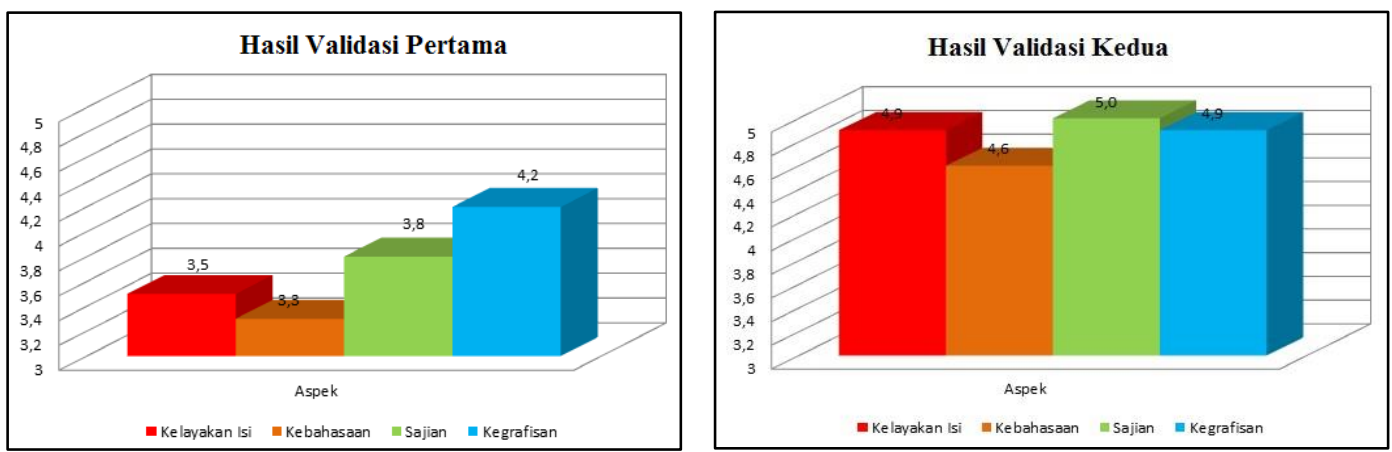

Gambar 1. Diagram Hasil Validasi Pakar/ Ahli

Uji coba dilakukan di satu sekolah dasar yang merupakan pilot projek kurikulum 2013 dengan subjek siswa kelas IV. Rata-rata total hasil pretes adalah 51 setelah dilaksanakan pembelajaran menggunakan produk bahan ajar yang telah divalidasi kemudian menghasilkan rata-rata total hasil postes 86 . Berikut rincian prestasi belajar untuk setiap muatan pelajaran pada pembelajaran tematik :

Tabel 1. Perbandingan Hasil Pretes dan Postes

\begin{tabular}{|c|c|c|}
\hline Mata Pelajaran & Rata-rata hasil pretes & Rata-rata hasil postes \\
\hline PPKn & 33 & 80 \\
\hline IPS & 72 & 91 \\
\hline IPA & 49 & 86 \\
\hline
\end{tabular}

Hasil uji hipotesis disimpulkan bahwa : 1) terdapat pengaruh pemanfaatan bahan ajar tematik berbasis saintifik terhadap prestasi belajar PPKn; 2) terdapat pengaruh pemanfaatan bahan ajar tematik berbasis saintifik terhadap prestasi belajar IPS; 3) terdapat pengaruh pemanfaatan bahan ajar tematik berbasis saintifik terhadap prestasi belajar IPA; 4) pemanfaatan bahan ajar tematik berbasis saintifik dapat menghasilkan nilai lebih besar dari KKM yaitu 80 .

Pelaksanaan uji coba sekaligus diperoleh data penilaian guru dan respon siswa. Rata-rata hasil penilaian guru adalah 4,0 dengan kategori setuju karena bahan ajar tematik berbasis saintifik membantu guru dalam memfasilitasi proses pembelajaran dengan baik. 
Tabel 2. Hasil Penilaian Guru

\begin{tabular}{|c|c|c|}
\hline NO. & ASPEK YANG DINILAI & NILAI \\
\hline 1. & Bahan ajar disusun secara menarik & 4 \\
\hline 2. & $\begin{array}{l}\text { Tujuan pembelajaran dalam Bahan Ajar sesuai dengan KI dan } \\
\text { KD }\end{array}$ & 4 \\
\hline 3. & $\begin{array}{l}\text { Penyampaian materi dengan menggunakan Bahan Ajar lebih } \\
\text { efisien dan efektif sesuai dengan waktu yang disediakan }\end{array}$ & 3 \\
\hline 4. & $\begin{array}{l}\text { Bahan ajar memudahkan guru dalam melaksanakan } \\
\text { pembelajaran tematik }\end{array}$ & 4 \\
\hline 5. & $\begin{array}{l}\text { Bahan ajar mendorong siswa memahami, menerapkan dan } \\
\text { mengembangkan pola pikir rasional. }\end{array}$ & 4 \\
\hline 6. & Bahan Ajar membantu siswa melakukan kegiatan pengamatan & 5 \\
\hline 7. & $\begin{array}{l}\text { Bahan Ajar memudahkan siswa dalam mengumpulkan } \\
\text { informasi }\end{array}$ & 4 \\
\hline 8. & Bahan Ajar membantu siswa berpikir analitis dan logis & 4 \\
\hline 9. & Bahan A jar membantu siswa dalam mengkomunikasikan hasil & 5 \\
\hline 10. & $\begin{array}{l}\text { Bahan ajar membantu siswa dalam menghubungkan antara fakta } \\
\text { dan konsep }\end{array}$ & 4 \\
\hline 11. & $\begin{array}{l}\text { Bahan Ajar membantu siswa mengolah informasi yang telah } \\
\text { dikumpulkan }\end{array}$ & 5 \\
\hline 12. & $\begin{array}{l}\text { Materi dan soal yang disajikan sesuai dengan tujuan } \\
\text { pembelajaran }\end{array}$ & 5 \\
\hline 13. & Konsep dalam materi tepat dan sesuai & 4 \\
\hline 14. & $\begin{array}{l}\text { Bahan ajar membantu siswa menjadi lebih mandiri dalam } \\
\text { belajar }\end{array}$ & 4 \\
\hline 15. & Bahasa dan kalimat digunakan jelas dan memudahkan siswa & 3 \\
\hline 16. & $\begin{array}{l}\text { Siswa merasa tertarik dan antusias saat belajar menggunakan } \\
\text { bahan ajar }\end{array}$ & 4 \\
\hline 17. & Bahasa yang digunakan komunikatif & 4 \\
\hline 18. & $\begin{array}{l}\text { Bahan ajar dapat menginspirasi guru untuk lebih kreatif dalam } \\
\text { menyajikan materi }\end{array}$ & 4 \\
\hline 19. & Penulisan istilah baik dan benar & 3 \\
\hline & Rata-rata & 4,0 \\
\hline
\end{tabular}

Hasil rata-rata respon siswa terhadap bahan ajar tematik berbasis saintifik yang digunakan dalam pembelajaran memperoleh rata-rata untuk pilihan jawaban a sebanyak $64 \%$, pilihan jawaban b sebanyak $30 \%$, dan pilihan jawaban c sebanyak $6 \%$. Hasil tersebut menunjukan bahwa bahan ajar yang digunakan oleh dalam kegiatan pembelajaran menghasilkan respon siswa yang sangat baik, karena jumlah presentase siswa yang memilih pilihan jawaban a dan $b$ adalah 94\%. Berikut diagram hasil respon siswa :

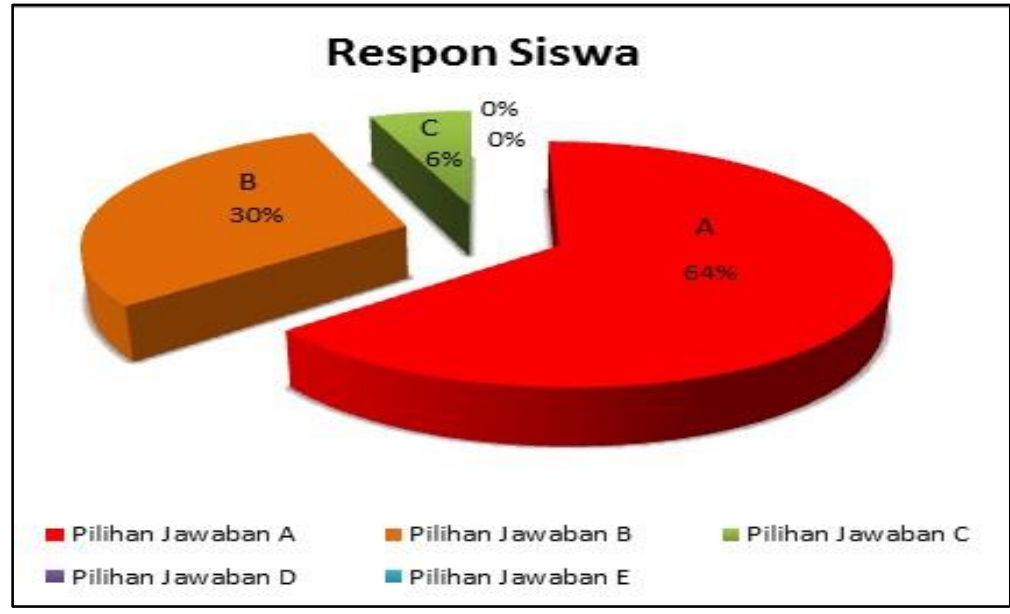

Gambar 4.2 Diagram Hasil Respon Siswa

\section{SIMPULAN DAN SARAN}

Berdasarkan hasil penelitian pengembangan Bahan Ajar Tematik Berbasis Saintifik, dapat disimpulkan sebagai berikut :
1. Kondisi faktual pemanfaatan bahan ajar pada pembelajaran tematik di kurikulum 2013 ditemukan bahwa produk bahan ajar yang sudah ada belum mampu memfasilitasi kebutuhan proses pembelajaran, sehingga perlu 
dikembangkan bahan ajar tematik berbasis saintifik untuk memfasilitasi kesenjangan yang muncul dalam pembelajaran tematik menggunakan pendekatan saintifik.

2. Hasil pengembangan bahan ajar tematik berbasis saintifik tema tempat tinggalku subtema keunikan daerah tempat tinggalku pembelajaran 1 untuk siswa SD kelas IV telah disesuaikan dengan karakteristik pembelajaran tematik yang integratif, hierarkis, holistik dan kongkret. Selain itu, langkah-langkah pembelajaran pada bahan ajar sudah menggunakan langkah-langkah ilmiah berupa mengamati, menanya, menanya, mengumpulkan informasi, mengolah informasi, dan mengkomunikasikan.

3. Hasil pengembangan bahan ajar tematik berbasis saintifik tema tempat tinggalku subtema keunikan daerah tempat tinggalku pembelajaran 1 untuk siswa SD kelas IV yang telah dinilai oleh dua pakar mengahasilkan rata-rata nilai sebesar 3,7 pada validasi pertama dan 4,9 pada validasi kedua dengan kriteria sangat valid dan layak digunakan tanpa revisi.

4. Hasil Uji hipotesis meliputi : 1) terdapat pengaruh pemanfaatan bahan ajar tematik berbasis saintifik pada tema tempat tinggalku subtema keunikan daerah tempat tinggalku pembelajaran 1 terhadap prestasi belajar PPKn; 2) terdapat pengaruh pemanfaatan bahan ajar tematik berbasis saintifik pada tema tempat tinggalku subtema keunikan daerah tempat tinggalku pembelajaran 1 terhadap prestasi belajar IPS; 3) Terdapat pengaruh pemanfaatan bahan ajar tematik berbasis saintifik pada tema tempat tinggalku subtema keunikan daerah tempat tinggalku pembelajaran 1 terhadap prestasi belajar IPA; 4) pemanfaatan bahan ajar tematik berbasis saintifik dapat menghasilkan nilai lebih besar dari KKM yaitu 80 .

5. Respon guru terhadap bahan ajar tematik berbasis saintifik pada tema tempat tinggalku subtema keunikan daerah tempat tinggalku pembelajaran 1 menghasilkan rata-rata nilai sebesar 4,0 atau dengan kriteria setuju. Dapat disimpulkan bahwa pemanfaatan bahan ajar tematik berbasis saintifik membantu guru dalam memfasilitasi proses pembelajaran.

6. Respon siswa terhadap bahan ajar tematik berbasis saintifik pada tema tempat tinggalku subtema keunikan daerah tempat tinggalku pembelajaran 1 menghasilkan respon siswa dengan pilihan jawaban a sebanyak $64 \%$ dengan kriteria bahan ajar sangat menarik/ sangat membantu/ sangat jelas/ sangat memotivasi/ sangat menarik/ sangat menginspirasi, pilihan b sebanyak $30 \%$ atau kriteria bahan ajar menarik/ membantu/ jelas/ memotivasi/ menarik/ menginspirasi/, dan pilihan jawaban c sebanyak $6 \%$ atau dengan kriteria bahan ajar cukup menarik/ cukup membantu/ cukup jelas/ cukup memotivasi/ cukup menarik/ cukup menginspirasi.

Berdasarkan hasil penelitian dan simpulan, maka untuk perbaikan penelitian di masa yang akan datang terdapat beberapa saran yang dapat disampaikan antara lain :

1. Bahan ajar pada kurikulum 2013 masih dalam proses penyempurnaan secara berkelanjutan, sehingga perlu dilakukan analisis dan pengembangan secara menyeluruh agar dapat membantu pihak terkait dalam pengadaan bahan ajar (buku guru dan buku siswa) untuk kurikulum 2013. Bahan ajar berupa buku guru dan buku siswa akan dijadikan sumber utama dalam kegiatan pembelajaran tematik di kurikulum 2013, untuk itu ketersediaan bahan ajar yang baik sangat dibutuhkan, sehingga landasan awal perubahan kurikulum dapat tercapi sesuai target.

2. Penggunaan bahan ajar tematik berbasis saintifik akan menghasilkan hasil optimal apabila aplikasi penggunaan bahan ajar dirancang dengan menggunakan strategi yang menarik. 
Oleh karena itu, sebaiknya pemanfaatan bahan ajar tematik berbasis sainitik dipadukan dengan model pembelajaran dan strategi pembelajaran yang menarik agar siswa lebih antusias dalam proses pembelajaran.

3. Hasil pengembangan bahan ajar tematik berbasis saintifik dapat digunakan sebagai referensi penelitian selanjutnya dan dapat dijadikan konsep dalam mengembangkan produk bahan ajar pada tema yang lain. Sebaiknya penelitian pengembangan bahan ajar untuk penelitian selanjutnya dilakukan uji keefektifitasannya bukan hanya kepraktisannya saja.

4. Hasil penelitian dan pengembangan bahan ajar tematik berbasis saintifik selanjutnya dapat dilakukan penyebarluasan dengan dilakukan dessiminasi pada skala yang lebih luas untuk memperoleh saran perbaikan.

5. Pengembangan bahan ajar sebaiknya memperhatikan desain tampilan yang menarik agar siswa antusias untuk belajar. Penyajian gambar yang akan digunakan juga harus sesuai dengan konsep yang akan dipelajari, sehingga pemilihan gambar yang sesuai dengan konsep materi juga harus diperhatikan.

\section{DAFTAR PUSTAKA}

Abdullah, R.S. 2014. Pembelajaran Saintifik Untuk Implementasi Kurikulum 2013. Jakarta : Bumi Aksara
BPSDMP dan KPMP. 2013. Pembelajaran Tematik Terpadu. Kementrian Pendidikan dan Kebudayaan.

BPSDMP dan KPMP. 2013. Konsep Pendekatan Saintifik. Kementrian Pendidikan dan Kebudayaan.

Daryanto dan Dwicahyono, A. 2014. Pengembangan Perangkat Pembelajaran. Yogyakarta: Gava Media.

Prastowo, A. 2013. Pengembangan Bahan Ajar Tematik Panduan Lengkap Aplikatif. Yogyakarta : DIVA Press.

Permata,L.S. (2014). "Pengaruh Pembelajaran Matematika Dengan Pendekatan Scientific Pada Pokok Bahasan Kubus Dan Balok Terhadap Kemampuan Berpikir Kreatif Siswa Kelas Viii Semester Genap Smp Negeri 1 Banyuputih Tahun Ajaran 2013/2014". UNEJ Digital Rrepository. [Online]. Tersedia : http://repository.unej.ac.id/handle/12 3456789/60591. (Diakses tanggal 14 Desember 2014, 07:55)

Thiagarajan,S., Semmel, D. and Semmel, M. 1974. Instructional Development For Training Teachers of Exceptional Children A Sourcebook. National Center for Improvement of Educational Systems Washington, D.C. : Indiana Univ., Bloomington. Center for Innovation inTeaching the Handicapped. 